\title{
MANAJEMEN RISIKO TERHADAP BLACK SWAN EVENT MARET 2020 DI INDONESIA. STUDI KASUS EFEK COVID-19 TERHADAP PASAR MODAL INDONESIA
}

\author{
Andreas Kiky \\ Universitas Pradita \\ andreas.kiky@pradita.ac.id
}

\begin{abstract}
COVID-19 has caused many significant impacts on various businesses in Indonesia. This pandemic was first announced by government on March 2020 and as the result, Indonesia Composite Index moved toward down trend. To investigate this matter, this result applied event study and non-parametric test (Wilcoxon Signed Test) on observed IHSG from December 2019 to March 2020. The result confirmed that indeed after announcement, IHSG significantly decreased and loss almost $50 \%$ from initial value in December 2019. This research also suggests that this event cannot consider as Black Swan event because IHSG moved gradually decrease since February 2020. This research also offers some contingency plan and risk management concept to overcome this pandemic crisis.
\end{abstract}

Keywords: Black Swan, Risk Management, COVID-19 Pandemic, Event Study, Contingency Plan, Contingency Table

\section{PENDAHULUAN}

Dalam dinamika pasar modal, tentunya diperlukan sikap optimis dari investor untuk dapat mendorong meningkatnya capital inflow yang masuk ke sebuah negara. Demikian juga outlook dari IHSG ketika di awal tahun 2020, sejauh itu menunjukan sinyal yang positif dan baik. IHSG sendiri pada awal tahun 2020 menyentuh nilai hampir 6,300 dan berfluktuasi tidak pernah jatuh di bawah angka 6,000 hingga akhir bulan januari 2020. Akan tetapi arah pergerakan indeks berubah drastis pada awal februari 2020. Penurunan nilai IHSG bahkan terus berlanjut hingga maret
2020. IHSG yang pada awalnya berada di angka 6,000 an kehilangan nyaris $50 \%$ dari nilai tersebut ketika di awal maret 2020. Pertanyaan yang menarik dari event ini adalah apa penyebabnya? Tentunya hampir semua orang pembaca artikel ini bisa menebak apa yang terjadi pada Februari 2020, atau lebih tepatnya apa yang terjadi ketika tahun baru imlek pada Januari 2020, pandemic COVID19. Wabah dari COVID-19 menyebabkan gangguan pernapasan akut pada manusia yang mengakibatkan kota Wuhan, tempat di mana wabah ini dimulai harus memutuskan lockdown demi memperlambat laju penyebaran 
virus. Sejauh ini pada bulan Januari 2020, Indonesia belum merasakan efek dari wabah COVID-19 secara berarti dikarenakan belum adanya kasus yang ditemukan di Indonesia (setidaknya hingga Maret 2020). Berbagai perdebatan sudah dimulai ketika wabah ini dimulai di China, bagaimana respon pemerintah dan tindakan pencegahan yang tepat untuk mengatasi pandemic global tersebut (sekali lagi, sebelum Maret 2020 COVID-19 belum dinyatakan sebagai pandemic global). Akan tetapi artikel ini tidak akan memperdebatkan bagaimana penanggulangan dan respon pemerintah terhadap pandemic global tersebut melainkan pada "special event" yakni COVID-19 itu sendiri dan efeknya terhadap pasar modal dan nilai tukar di Indonesia. Pernahkan kalian mendengar sebuah istilah "black swan"? Setidaknya apakah kalian pernah berjumpa dengan angsa hitam? Black swan adalah sebuah istilah yang mengacu pada sebuah event dengan kemungkinan sangat kecil (nyaris tidak bisa diprediksi, setidaknya dengan statistic) tetapi dapat berdampak sistematik dan besar. istilah ini diperkenalkan oleh (Taleb, 2009) dalam bukunya yang berjudul "black swan". Yang menarik dari kejadian ini adalah sehebat apa pun matematika dan statistic dalam membuat prediksi, begitu adanya kejadian ini, maka dampak yang ditimbulkan dapat mengakibatkan pergeseran hasil prediksi yang sangat jauh. Tentunya beberapa penyesuaian perlu dilakukan sebagai respon atas situasi tersebut. Yang menjadi novelty dari penelitian ini adalah pembahasan mengenai black swan sebagai topik penelitian terkait ilmu keuangan. Oleh karena itu penelitian ini menggagas beberapa masalah yang akan diangkat yakni:

1. Bagaimana dampak black swan (dalam kasus ini COVID-19) secara empiris pada IHSG dan nilai tukar rupiah di Indonesia?

2. Mitigasi seperti apa yang dapat dilakukan untuk meminimalisir risiko atas efek COVID-19 secara makro di Indonesia? 


\section{TELAAH LITERATUR}

Black Swan

Seperti yang telah dijelaskan di atas, black swan merupakan sebuah event yang sulit sekali untuk diprediksi (dengan kata lain kemungkinan terjadinya event tersebut sangat kecil), akan tetapi dapat berdampak sangat signifikan. Impact yang ditimbulkan dari black swan dapat dikategorikan sangat besar, sebagai contoh, sebuah kejadian serangan teroris 11 September merupakan salah satu contoh kejadian yang tergolong black swan dan berakibat sangat besar bagi Amerika Serikat (Taleb, 2009). Sebuah kajian empiris juga dilakukan pada pasar modal Shanghai dan Shen Zhen pada 24 Agustus 2015 oleh (Lin \& Tsai, 2019). Penelitian ini menggunakan quantile autoregression unit-root test untuk mengindetifikasi convergence atau dispersed pada harga saham ketika event terjadi pada 24 Agustus 2015. Hasil penelitian menunjukan kejadian black swan ini dapat dideteksi sejak dini pada 28 Mei 2015 ketika terjadinya sudden drop yang kemudian diikuti dengan penurunan secara drastic sebagai reaksi atas overreaction dan underaction. Kajian mengenai black swan itu sendiri erat kaitannya dengan manajemen risiko (Aven, On the Meaning of a Black Swan in a Risk Context, 2013). Dalam risk assessment dan management diperlukan banyak sekali kajian ilmiah untuk pengukuran probabilitas dan risiko sebuah event. Memang yang menjadi sebuah kritik dari Taleb adalah dibutuhkan tools dan pengembangan ilmiah untuk sebuah event yang sebenarnya masih dapat terjadi sekalipun dengan nilai kemungkinan yang sangat kecil (bahkan kurang dari 1\%) tetapi jika itu terjadi maka dapat mengakibatkan kerugian yang tinggi. (Aven, Implications of Black Swans to the Foundations and Practice of Risk Assessment and Management, 2015) lebih jauh akhirnya mencoba mengklasifikasikan black swan menjadi 3 kategori black swan dengan tujuan dapatnya dilakukan contingency plan dalam penanangannya. Dengan membagi black swan tersebut menjadi 3 kategori maka harapannya dapat dilakukan penanganan yang lebih tepat dan responsive jika memang event itu terjadi. Penelitian ini mencoba untuk menjawab pendekatan praktikal dalam manajemen risiko terhadap event event yang sering kali diabaikan dikarenakan assessment menganggap 
likelihood nya sangat kecil. Sejauh penelitian tersebut, black swan sepertinya masih bisa di handle dengan baik jika memang dalam manajemen risiko assessment terhadap black swan itu sendiri tidak dikesampingkan. Tentunya dalam penilaian (assessment) keterbatasannya ada pada knowledge dan information. Penelitian mengenai black swan sendiri tidak terbatas pada efek pada sektor finansial saja tapi juga pada sektor energy dan teknologi (Krupa \& Jones, 2013). Penelitian ini menekankan bagaimana teori black swan dapat diadaptasi pada penggunaan teknologi dan prediksinya dalam jangka panjang. Tantangnya adalah dengan adanya kajian black swan tersebut maka kita boleh skeptic terhadap semua prediksi (forecast) mengenai kebutuhan energy yang ada sekarang. Apa yang penting sekarang adalah bagaimana mengevaluasi sistem untuk environmental externalities sehingga dapat memberikan manfaat lebih besar bagi masyarakat secara luas. (Taylor \& Williams, 2008) dalam sebuah working paper menyatakan pada saat krisis 2007-208 terjadi lonjakan yang tidak biasa pada spread LIBOR yang dapat mempengaruhi kebijakan moneter. Dalam penelitian ini dikenalkan TAF, sebuah auction facility untuk mengurangi lonjakan spread tersebut. Dalam pengembangannya (dengan noarbritage model) dengan meningkatnya counterparty risk antar bank, maka itu dapat mengakibatkan meningkatnya spread dan penelitian ini menemukan secara empiris tidak ada bukti bahwa TAF efektif dalam mengurangi spread tersebut.

Classical Works on Finance, Risk, Return \& Behavioral Studies

Dalam buku intelligent investor (Graham \& Zweig, 2006), memperkenalkan konsep valued investing. Umumnya dalam mengkaji sebuah investasi maka investor cenderung fokus kepada nilai intrisik dari aset daripada spekulasi akan volatilitas harga. Tentunya menjadi sebuah tantangan tersendiri bahwa harga yang terbentuk di pasar merupakan campuran dari nilai intrinsic dan noise (atau speculator) yang ingin mengambil keuntungan dari volatilitas harga. (Ross, Westerfield, Jordan, Lim, \& Tan, 2014) dalam buku manajemen keuangan klasik umumnya dalam manajemen portofolio maka penting sekali bagi investor untuk mempertimbangkan expected return dan 
juga simpangan dari return dengan berbagai skenario yang mungkin terjadi. Oleh karena itu dalam ilmu keuangan risiko dapat terukur dari simpangan dari expected return dari sebuah aset. Yang menjadi kritik dari black swan adalah nilai expected return itu sendiri mungkin dapat mendekati nilai aktual jika kondisi normal, akan tetapi ketika black swan terjadi maka kemungkinan error yang terjadi menjadi sangat tinggi (Taleb, 2009). Lebih jauh lagi banyak beberapa aspek yang tidak dapat terukur dengan mengandalkan simpangan. Aspek seperti overreaction dan panic atau overoptimistic dapat menyebabkan volatilitas menjadi tidak terkendali dan menjadi penyebab bagaimana statistic gagal dalam memprediksi sebuah event. Sekalipun demikian, (Lin \& Tsai, 2019) memang menggaris bawahi bahwa pada black swan di China, terdeteksi dini pada 3 bulan sebelum event terjadi. Beberapa literature menekankan pentingnya untuk mempertimbangkan perilaku manusia yang terkadang lebih sering tidak rasional dalam mengambil keputusan. (Thaler, Misbehaving: The Making of Behavioral Economics,
2016) dan (Thaler, Nudge: Improving Decisions About Health, Wealth, and Happiness, 2009) merupakan kumpulan hasil penelitian bagaimana dalam membuat keputusan terkadang manusia gagal bertindak secara efisien. Secara psikologis hal ini memang dijelaskan oleh (Kahneman, 2013) bahwa pada dasarnya manusia menggunakan sistem berpikir automatis dan sistematis yang akan aktif sesuai dengan situasi dan mental effort yang dibutuhkan untuk membuat sebuah keputusan. Umumnya ketika kondisi mental manusia yang sudah lelah (mental depletion) maka sistem 1 akan mengambil ahli peran untuk membuat keputusan yang umumnya berakhir pada inefficiency. Penelitian ini tidak berfokus pada berbagai metode statistic yang rumit dan juga tidak pada kajian puzzle perilaku. Penelitian ini berusaha untuk mencari benang merah dari terjadinya event black swan yang terjadi saat COVID-19 di Indonesia dan menuangkan gagasan untuk contingency plan yang dapat dilakukan disaat situasi seperti ini. 


\section{METODOLOGI PENELITIAN}

Penelitian ini adalah penelitian kuantitatif yang bersifat deskriptif dan inferensial. Data yang digunakan dalam penelitian ini adalah data sekunder, berdasarkan data historis IHSG sejak Januari 2020 hingga Maret 2020. Selain itu jumlah pasien COVID-19 diambil dari publikasi resmi tim penanggulangan Corona dari pemerintah Republik Indonesia, dan data nilai tukar rupiah terhadap USD diambil dari meta data Bank Indonesia. Untuk memahami bagaimana dinamika data, maka analisis korelasi digunakan untuk mengecek bagaimana impact dari jumlah pasien COVID-19 terhadap pergerakan IHSG dan nilai tukar. Pearson Correlation digunakan sebagai indikator korelasi dalam menganalisis hubungan antara event black swan tersebut dengan variabel yang diamati

\section{HASIL \& ANALISIS}

Analisis Deskriptif

COVID-19 diumumkan pertama kali di Indonesia pada 2 maret 2020. Pandemik ini sendiri telah dimulai sejak akhir Desember 2019 di Wuhan, China. Berikut ini adalah paparan data IHSG pada bulan Desember 2019 hingga Maret 2020. Nilai IHSG sendiri pada
(IHSG dan Nilai Tukar). Selain itu kaidah event study juga diterapkan untuk mengamati pergerakan IHSG 6 dan 10 hari sebelum event date (2 Maret 2020), serta 6 dan 10 hari setelah event date. Dan non-parametric test (wilcoxon sign test) digunakan untuk membandingkan 6 hari dan 10 hari sebelum dan sesudah. Apa yang menjadi kekurangan dari penelitian ini adalah tidak adanya secara scientific pengukuran dari event black swan itu sendiri. Penelitian-penelitian terdahulu berlomba-lomba untuk membuat "mesin prediksi" yang canggih, akan tetapi penelitian ini mencoba untuk menuangkan ide tindakan-tindakan seperti apa yang dapat dilakukan ketika event ini terjadi.

awal Desember 2019 masih pada nilai yang cukup tinggi yakni di atas 6,000 point. Sejauh pengamatan hingga Februari 2020, nilai IHSG masih cukup stabil dalam rentang di antara 6,000 hingga 5,800. Akan tetapi sepertinya terjadi sedikit penurunan (tidak banyak) pada awal Februari 2020, pertengahan Februari yang selanjutnya diikuti 


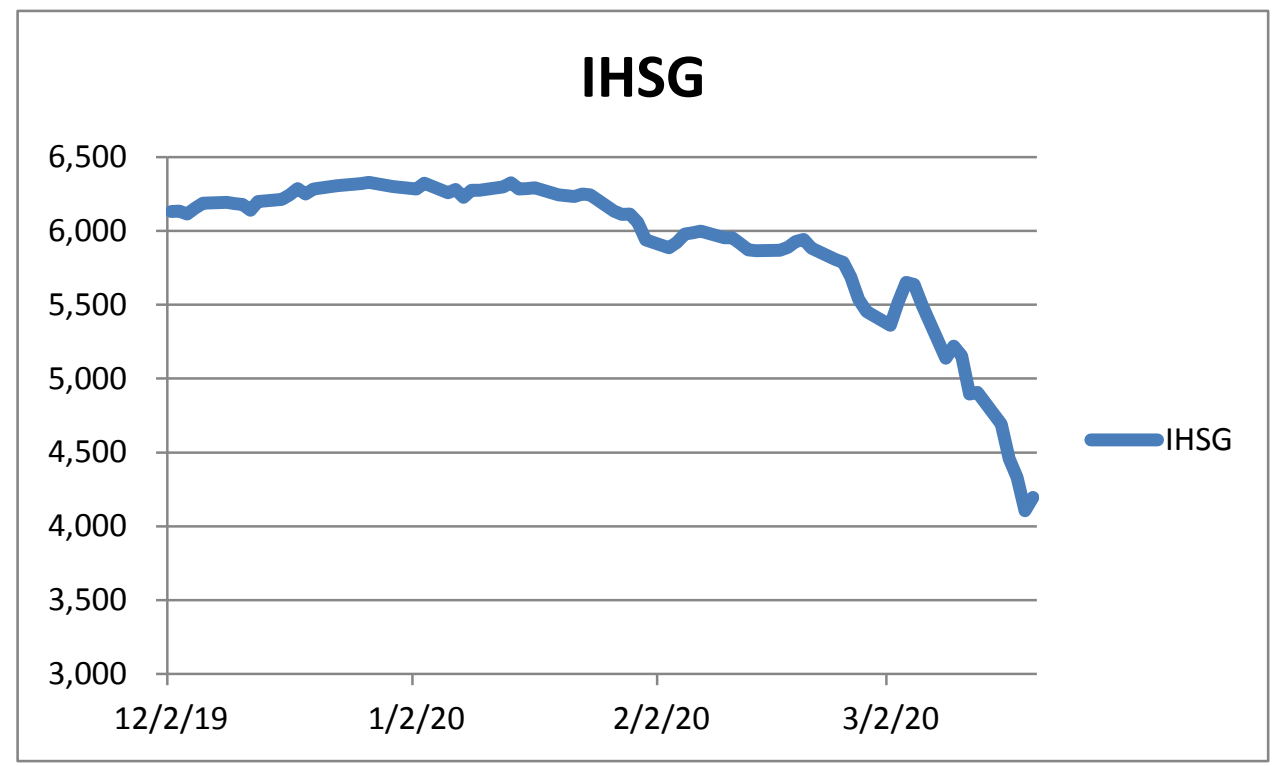

Gambar 4.1 Pergerakan IHSG Desember 2019 hingga Maret 2020

Grafik di atas secara jelas menunjukan terjadi downtrend yang sangat drastis pada awal bulan Maret. Jika dinilai lebih lanjut maka penuruan nilai yang terjadi bisa mencapai hampir $50 \%$ dari nilai mula-mula di awal Desember 2019. Event black swan yang terjadi pada penelitian ini (D0) adalah 2 Maret 2020 ketika pemerintah Indonesia pertama kali mengumumkan pengumuman resmi dari kondisi Indonesia. Berikut ini adalah data perubahan IHSG per hari.

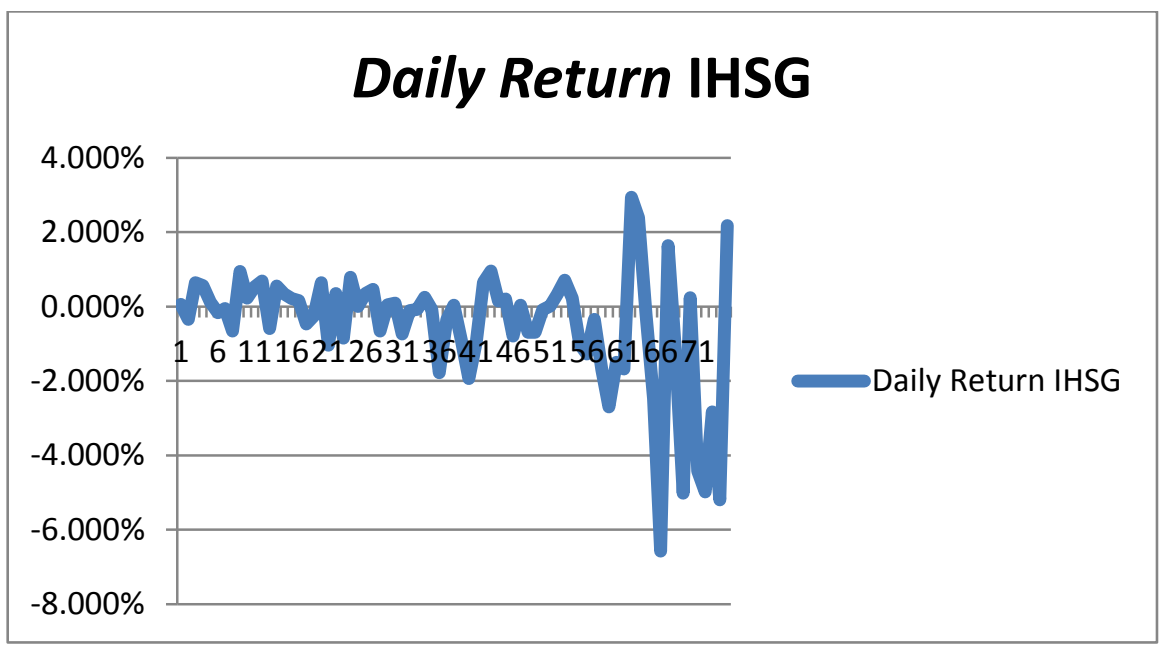

Gambar 4.2 Return Harian IHSG dari Desember 2019 - Maret 2020 
Pergerakan harian IHSG menunjukan volatilitas yang sangat tinggi pada akhir periode pengamatan (Maret 2020).
Fluktuasi perubahan (return) IHSG meningkat hingga bisa mencapai 4 $6 \%$ per hari pada bulan tersebut.

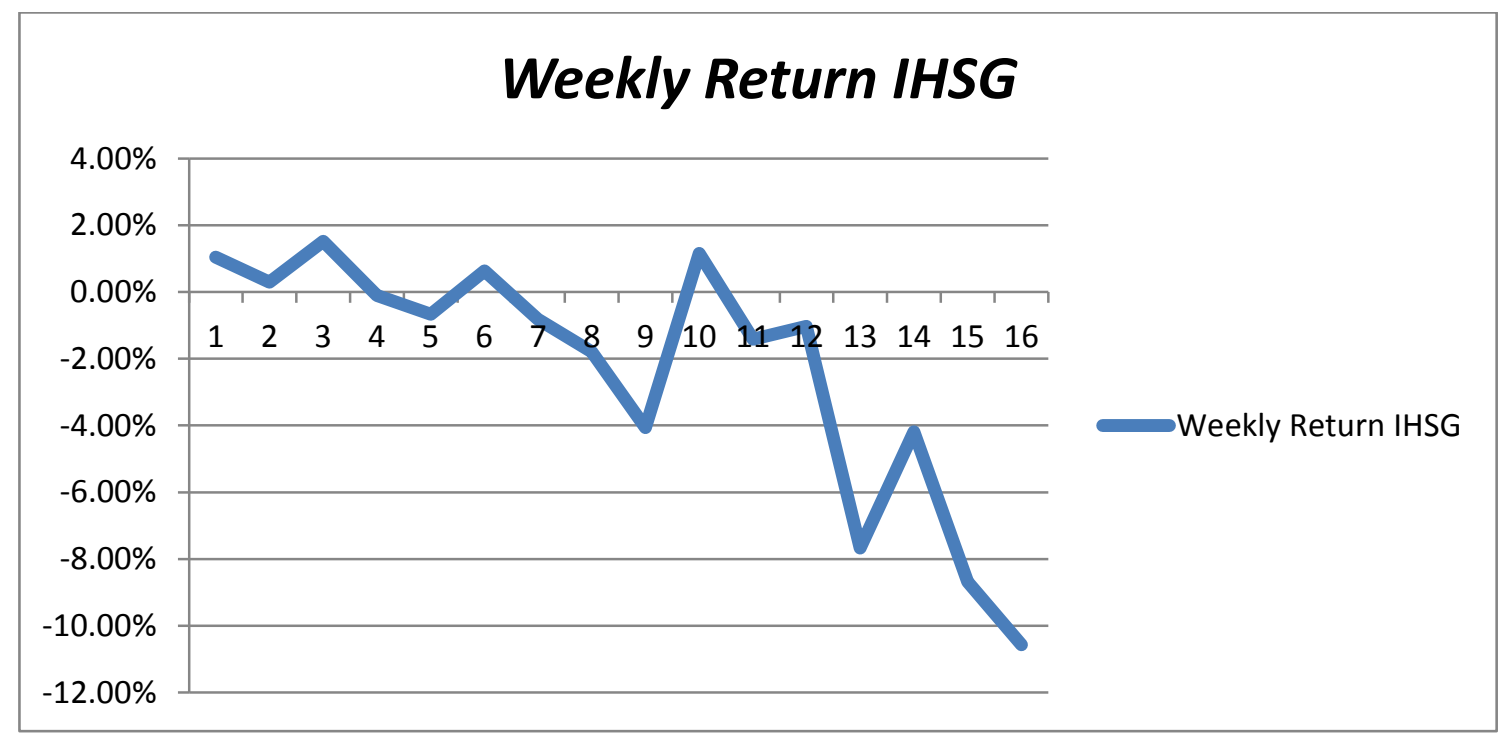

Gambar 4.3 Return Mingguan IHSG dari Desember 2019 - Maret 2020

Pergerakan IHSG berdasarkan data mingguan lebih dapat mencerminkan trend yang sebenarnya dari IHSG disaat pademik ini. Berdasarkan data mingguan tersebut down trend sudah bisa dideteksi sejak minggu ke-7 ketika trend penurunan sudah terlihat. Trend tersebut terlihat terus berlanjut dan belum menunjukan sama sekali tanda koreksi terhadap pergerakan IHSG. Secara dramatis pergerakan IHSG di awal bulan Maret hingga tanggal 20 Maret 2020 menunjukan penurunan hingga 22\%. Berdasarkan data deskriptif tersebut trend penurunan paling drastis terjadi pada bulan Maret 2020. Dengan menggunakan statistic maka kita dapat melihat dan sebenarnya kejadian ini (COVID-19) sebenarnya bukan tergolong black swan yang tidak dapat diprediksi. Sejauh ini, peneliti berpendapat karena kejadian ini sendiri sudah terjadi secara pada Desember 2019, maka sebenarnya yang terjadi di Indonesia sendiri tergolong sebagai delayed effect. Hanya saja kenapa bisa terjadi delay hingga 3 bulan, sejauh ini bisa dikarenakan menunggu pernyataan 
resmi dari pemerintah saja. Jadi, yang menarik dari kejadian ini, katakan saja pemerintah bertindak tidak terbuka, dan tetap diam, bisa jadi reaksi pasar (yang tercermin dari IHSG) tidak akan seperti ini. Namun memang benar bukan kebijakan seperti itu yang diinginkan publik dan seharusnya memang COVID-19 ini sudah bisa diprediksi jauh-jauh hari. Jadi jika ingin mengambil keuntungan dari situasi seperti ini, maka ketika pemerintah mengumumkan pengumuman COVID19, lebih baik anda menjual investasi anda sebelum terjun bebas. Selanjutnya, jika fenomana ini dianalisis dari perspektif event studies maka didapatkan hasil uji-t sebagai berikut. Untuk mendapatkan hasil uji-t, maka diterapkan beberapa asumsi sebagai berikut:

1. Jika dalam event study dalam mendeteksi abnormal return menggunakan CAPM dalam memprediksi expected outcomes maka dalam penelitian ini digunakan persamaan time-series naive model yang jika dirumuskan dapat dinyatakan sebagai $\mathrm{Yt}=$ $\mathrm{a}+\mathrm{Yt}-1+\mathrm{ei}$

2. Untuk memastikan tingkat keakuratan model naive dari sebaran data, maka yang dicek terlebih dahulu adalah nilai dari R-Square dari model tersebut.

3. Dari model persamaan naive maka diperoleh nilai estimasi yang cukup tinggi, yakni nilai $R$-Square nya mencapai $97.8 \%$ dari data Desember 2019 hingga Maret 2020.

4. Selanjutnya untuk uji-t, maka nilai $\mathrm{t}$ pada one tailed test diperoleh signifikan jika > $1.725 \quad(\mathrm{df}=20)$ 
Tabel 4.1 Hasil Event Check pada Day -10 hingga Day +10

\begin{tabular}{crrrrr} 
Day & IHSG & IHSG $_{(\mathrm{t}-1)}$ & \multicolumn{1}{c}{$\mathrm{E}(\mathrm{IHSG})$} & Diff IHSG & \multicolumn{1}{c}{ t-test } \\
-10 & 5,868 & 5,867 & $5,838.87$ & 28.65 & 0.36 \\
-9 & 5,887 & 5,868 & $5,839.49$ & 47.48 & 0.60 \\
-8 & 5,929 & 5,887 & $5,860.12$ & 68.67 & 0.86 \\
-7 & 5,942 & 5,929 & $5,904.53$ & 37.95 & 0.48 \\
-6 & 5,882 & 5,942 & $5,919.07$ & -36.82 & -0.46 \\
-5 & 5,807 & 5,882 & $5,855.13$ & -48.08 & -0.60 \\
-4 & 5,787 & 5,807 & $5,775.28$ & 11.86 & 0.15 \\
-3 & 5,689 & 5,787 & $5,754.14$ & -65.22 & -0.82 \\
-2 & 5,536 & 5,689 & $5,649.87$ & -114.18 & -1.43 \\
-1 & 5,453 & 5,536 & $5,487.19$ & -34.49 & -0.43 \\
0 & 5,361 & 5,453 & $5,399.08$ & -37.84 & -0.47 \\
1 & 5,519 & 5,361 & $5,301.99$ & 216.64 & $2.72 *$ \\
2 & 5,650 & 5,519 & $5,469.07$ & 181.06 & $2.27 *$ \\
3 & 5,638 & 5,650 & $5,608.69$ & 29.44 & 0.37 \\
4 & 5,499 & 5,638 & $5,595.95$ & -97.41 & -1.22 \\
5 & 5,137 & 5,499 & $5,447.75$ & -310.94 & $-3.90^{*}$ \\
6 & 5,221 & 5,137 & $5,063.71$ & 157.12 & $1.97 *$ \\
7 & 5,154 & 5,221 & $5,152.91$ & 1.20 & 0.02 \\
8 & 4,896 & 5,154 & $5,082.07$ & -186.32 & $-2.34 *$ \\
9 & 4,908 & 4,896 & $4,807.78$ & 99.79 & 1.25 \\
10 & 4,691 & 4,908 & $4,820.33$ & -129.68 & -1.63 \\
\hline & & & & & \\
\hline
\end{tabular}

Hasil penelitian menunjukan, memang terdapat beberapa hari nilai dari IHSG jauh melebihi prediksi IHSG yang bisa diukur dengan model Nä̈ve. Yang menarik, hari-hari sebelum pengumuman resmi pemerintah, pergerakan IHSG masih dalam batas normal jika para analis menggunakan Model Nä̈ve sebagai predictor. Akan tetapi anomaly ditemukan ketika D1. Pada saat pengumuman pergerakan IHSG masih dikatakan wajar berdasarkan event windows tersebut. Reaksi tidak wajar terjadi paling tinggi adalah ketika D (5). Jika dilihat dari jumlah penderita COVID-19 yang diumumkan memang pada D (5) terdapat peningkatan hingga $5 \mathrm{x}$ lipat (dari 4 orang menjadi 19 pasien). Setelah itu selanjutnya pergerakan IHSG masih berlanjut menuju down trend. Selain itu digunakan juga Wilcoxon sign test pada 6 dan 10 hari sebelum dan sesudah event untuk menambah validitas penelitian. Hipotesis untuk Wilcoxon signed test adalah sebagai berikut: 
Ho : Tidak ada perbedaan antara nilai IHSG sebelum dan sesudah event $\mathrm{Ha}$ : Terdapat perbedaan antara nilai IHSG sebelum dan sesudah event

Berdasarkan hasil Wilcoxon Signed Test, dibandingkan critical value untuk test statistic pada event 6 dan 10 hari sebelum dan sesudah. Nilai critical value untuk two tailed test dengan jumlah n 6 dan 10 adalah 6 dan 8. Hasil Wilcoxon Signed Test pada penelitian ini adalah 0 untuk $n=6$ dan 0 untuk $\mathrm{n}=10$. Kesimpulan yang diambil dari uji non parametris ini adalah terdapat perbedaan IHSG sebelum dan sesudah event.

\section{Correlation Analysis}

Tabel 4.2 Hasil Korelasi IHSG, Exchange Rate dan Jumlah Pasien Positif COVID-19

\begin{tabular}{lr}
\hline Variables & Correlation \\
\hline IHSG - EXC & -0.912517798 \\
IHSG - Patients & -0.92420037 \\
EXC - Patients & 0.98316414 \\
\hline
\end{tabular}

IHSG dan Nilai Tukar menunjukan korelasi yang sangat kuat, yakni -0.91 . Nilai ini sangat tinggi mengingat umumnya nilai korelasi 0.6 saja sudah bisa dikatakan memiliki hubungan yang erat. Ditemukan hubungan negatif antara IHSG dan Nilai Tukar dan hasil ini berarti pelemahan IHSG membuat nilai Dolar menjadi sangat mahal terhadap nilai rupiah (pelemahan rupiah). Selain itu korelasi antara baik IHSG dan Nilai Tukar dengan jumlah pasien juga sangat erat. Semakin bertambah pasien COVID-19, maka semakin buruk juga IHSG dan Nilai
Tukar. Sejauh ini data dari penelitian ini masih tergolong sangat sedikit, akan tetapi sudah ditemukan indikasi efek dari COVID-19 terhadap sektor keuangan (pasar modal) Indonesia. Baik berdasarkan event study dengan t-test pada event window maupun dengan uji non parametris (Wilcoxon Signed Test) ditemukan bahwa memang selama bulan Maret 2020, terdapat indikasi kuat penurunan baik IHSG dan Nilai Tukar Rupiah. Fokus utama penelitian ini adalah memberikan ide untuk penanganan COVID-19 yang telah di depan mata kita saat ini. Kita sudah 
tidak dapat menganggap impact yang ditimbulkan dari COVID-19 ini kecil, terutama untuk 2 hingga beberapa bulan ke depan. Jika tidak ditangani dengan baik dengan manajemen risiko dan contingency plan yang baik maka efek yang ditimbulkan dapat sangat buruk. Sejauh ini memang dari sektor keuangan, COVID-19 berhasil mengikis nilai perusahaan terbuka hingga hampir $50 \%$. Menurut penulis fokus utama dari penanganan COVID-19 ada pada 2 aspek utama yakni:

1. Meredam penyebaran lebih jauh (mengurangi) peluang bertambahnya pasien COVID-
19

2. Mengambil tindakan nyata untuk menjaga penurunan ekonomi dan dampak sosial yang mungkin terjadi.

Untuk lebih detail, berikut ini adalah contingency plan yang mungkin bisa dilakukan di tengah kondisi COVID-19 yang tidak menentu ini. Contingency plan ini merupakan manajemen risiko sederhana yang diharapkan memberikan inspirasi dan informasi penanggulangan risiko, tentunya tabel ini tidak berarti banyak tanpa adanya tim manajemen di lapangan.

\begin{tabular}{|c|c|c|c|c|c|c|}
\hline Event & Likelihood & Main Goal & Action Plan & Pelaksanaan & Efektivitas & Evaluasi/Improvement \\
\hline \multirow{7}{*}{$\begin{array}{l}\text { Normal } \\
\text { Spread } \\
\text { (last for } \\
3-6 \\
\text { Month) }\end{array}$} & \multirow{7}{*}{$60 \%$} & \multirow{7}{*}{$\begin{array}{l}\text { Meredam } \\
\text { Penyebaran }\end{array}$} & Penerapan Physical Distancing & & & \multirow{2}{*}{$\begin{array}{l}\text { Dalam pelaksanaan, tantangan terbesar } \\
\text { adalah masyarakat, masih banyak orang } \\
\text { yang butuh kerja dan transportasi umum } \\
\text { terutama Jakarta, memperbanyak ammada } \\
\text { dan frekuensi fasilitas umum bisa jadi } \\
\text { jawaban }\end{array}$} \\
\hline & & & $\begin{array}{l}\text { Menghimbau masyarakat yang } \\
\text { masih aktif untuk menjaga jarak } \\
\text { dan tidak berkumpul pada } \\
\text { kerumunan orang }\end{array}$ & $\begin{array}{c}\text { Sudah } \\
\text { Disosialisasikan }\end{array}$ & Baik & \\
\hline & & & $\begin{array}{c}\text { Membuat Sarana Umum untuk } \\
\text { Desinfektan } \\
\text { Membuat Bilik Desinfektan u/ } \\
\text { masyarakat (terutama pekerja } \\
\text { lapangan) atau bilik cuci tangan } \\
\text { dan sarana sejenisnya }\end{array}$ & $\begin{array}{c}\text { Diterapkan di } \\
\text { beberapa Provinsi }\end{array}$ & Baik & $\begin{array}{l}\text { Sudah diterapkan di berbagai daerah } \\
\text { (Jawa Barat \& Surabaya), padahal } \\
\text { Jakarta dan Banten lebih urgent dalam } \\
\text { implementasi hal ini, budget PEMDA } \\
\text { harus dioptimalkan dalam kondisi ini }\end{array}$ \\
\hline & & & Work From Home Campaign & $\begin{array}{c}\text { Diterapkan pada } \\
\text { industri yang } \\
\text { memungkinkan }\end{array}$ & Baik & \multirow{4}{*}{$\begin{array}{l}\text { Dikaji untuk perpanjangan waktu jika } \\
\text { memang pandemik masih berlanjut } \\
\text { hingga April, akan tetapi perlu } \\
\text { diperhatikan efeknya terhadap ekonomi } \\
\text { Media harusnya membuat pemberitaan } \\
\text { yang mendorong terjadinya Physical } \\
\text { Distancing, ketimbang sibuk membuat } \\
\text { berita "Klik Bait", Jika memang tidak } \\
\text { ada kepentingan politik maka harusnya } \\
\text { media bersatu untuk melawan pandemik } \\
\text { Perusahaan sektor telekomunikasi bisa } \\
\text { meningkatkan aksesabilitas rumah } \\
\text { tangga, dengan penyediaan kecepatan } \\
\text { internet yang lebih baik dan kuota } \\
\text { khusus untuk pelajar, sudah diterapkan } \\
\text { oleh Telkomsel }\end{array}$} \\
\hline & & & Media Boaster to Nudge Society & Belum & Baik & \\
\hline & & & $\begin{array}{l}\text { Meningkatkan Entertainment di } \\
\text { Rumah }\end{array}$ & \multirow[b]{2}{*}{$\begin{array}{l}\text { Diterapkan } \\
\text { sebagian }\end{array}$} & \multirow[b]{2}{*}{ Baik } & \\
\hline & & & $\begin{array}{l}\text { Kemudahan akses intemet dengan } \\
\text { paket data yang terjangkau }\end{array}$ & & & \\
\hline
\end{tabular}




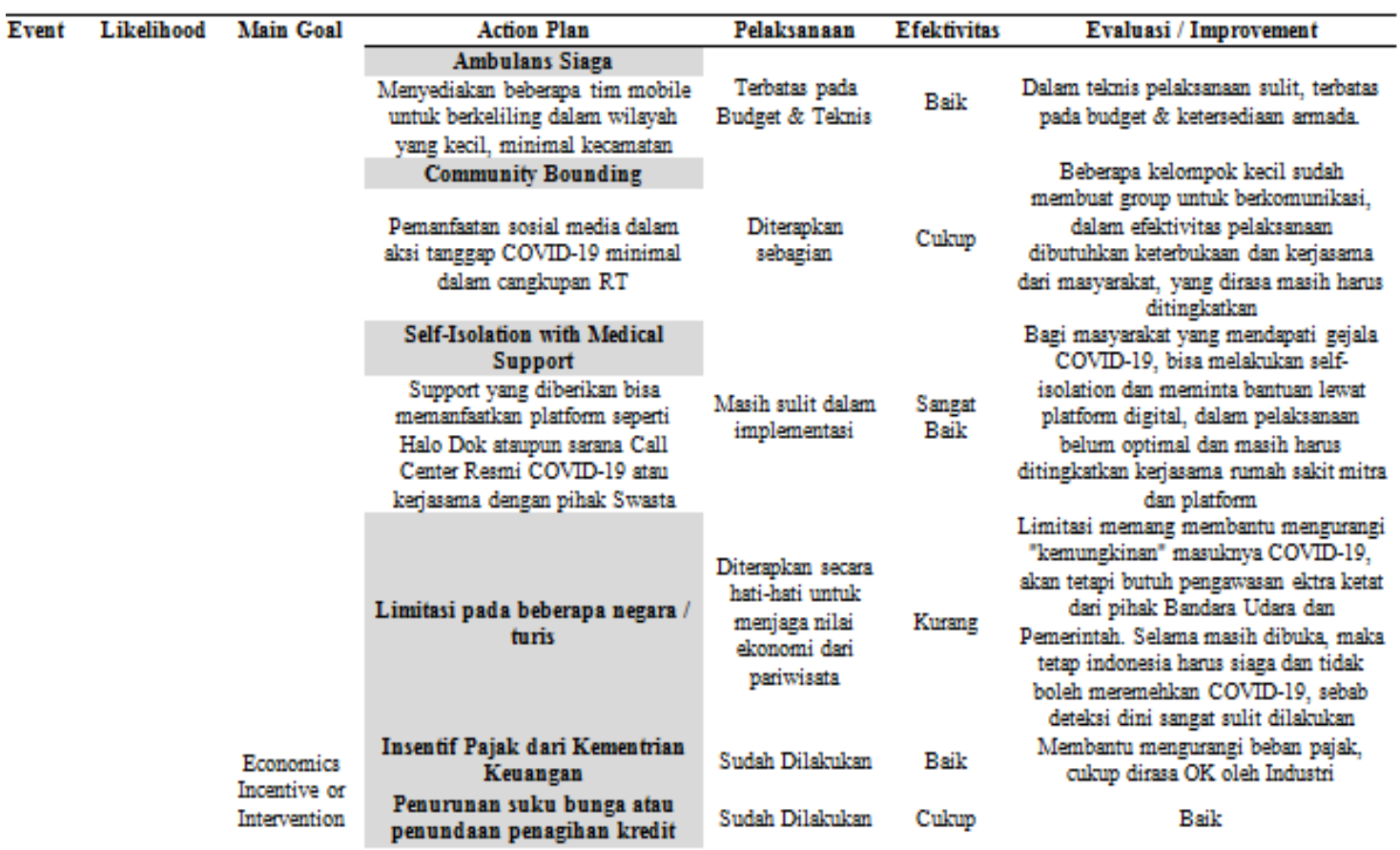

\begin{tabular}{|c|c|c|c|c|c|c|}
\hline \multirow[t]{4}{*}{ Event } & \multirow[t]{4}{*}{ Likelihood } & \multirow[t]{4}{*}{ Main Goal } & Action Plan & Pelaksanaan & Efektivitas & Evaluasi / Improvement \\
\hline & & & $\begin{array}{l}\text { Jika tejadi aksi panik, maks markst } \\
\text { bisa dilakukan suspend sementrars }\end{array}$ & Sudah Dilakukan & Cukup & $\begin{array}{l}\text { Peraturan umum bursa juga melakuksn } \\
\text { suspend jika terjadi unusual markat } \\
\text { activity, intensitas pengarwasn hans } \\
\text { ditingkatkan untuk menjoga bursa tetsp } \\
\text { stabil, terutama nilai-nilai perusahaen } \\
\text { BUMN }\end{array}$ \\
\hline & & & Logistic Control & & & Menjaga ketersadiaan barang, terutama \\
\hline & & & $\begin{array}{c}\text { Menjaga katersedisen pangan \& } \\
\text { kebutuhan polok serta harga pasar } \\
\text { yang stabil }\end{array}$ & Sudah Dilahukan & Baik & $\begin{array}{l}\text { mata rantai distribusi tetap berjalsn, } \\
\text { kementrian bisa memberikan insentif } \\
\text { juga untulk perusahaen seltor logistil } \\
\text { serta menjaga panic buying supays tidak } \\
\text { tejadi }\end{array}$ \\
\hline \multirow{5}{*}{$\begin{array}{l}\text { Rapid } \\
\text { Spread } \\
\text { (Last }>6 \\
\text { Months) }\end{array}$} & \multirow{5}{*}{$39 \%$} & \multirow{5}{*}{$\begin{array}{l}\text { Regional } \\
\text { Watch \& } \\
\text { High } \\
\text { Intensity } \\
\text { Control }\end{array}$} & $\begin{array}{l}\text { Penjagaan Batas-Batas Provinsi } \\
\text { Setiap warga yang keluar masuk } \\
\text { provinsi dijaga dan dicak suhu } \\
\text { badan, jika tertangkap bergajala } \\
\text { COVD-19 diamankan pada lobasi } \\
\text { karantina }\end{array}$ & $\begin{array}{c}\text { Dilahulkan jika } \\
\text { sudah dalsm fase } \\
\text { sangat burul: }\end{array}$ & Cukup & $\begin{array}{c}\text { Dilahulan jika sudah dalam fase sangat } \\
\text { buruk }\end{array}$ \\
\hline & & & $\begin{array}{l}\text { Peningkatan Tenaga Medis } \\
\text { Gabungan Provinsi }\end{array}$ & $\begin{array}{c}\text { Seding } \\
\text { Dilaksanalkan }\end{array}$ & Baik & $\begin{array}{c}\text { Kejasama Provinsi dan Antisipasi tetap } \\
\text { dilakulkan saksalipun masih dalam fase } \\
\text { nomal spread }\end{array}$ \\
\hline & & & $\begin{array}{l}\text { Quick Train \& Social Media } \\
\text { Campaign for Society }\end{array}$ & Sedeng Digarap & & Tetap bisa dilaksangkan dan diharapkan \\
\hline & & & $\begin{array}{l}\text { Adanya vidao / konten eduksai } \\
\text { masyaraksat tanggap COVID- } 19 \text { dan } \\
\text { penanganan pertama jiks } \\
\text { ditemukan }\end{array}$ & $\begin{array}{l}\text { Oleh Tim } \\
\text { Independent } \\
\text { seperti bebergeps } \\
\text { konten creator }\end{array}$ & Baik & $\begin{array}{l}\text { adinya kefja sama dengan influencer dan } \\
\text { pembuat konten (content creator) untuk } \\
\text { menggarap konsep video dan sosial } \\
\text { media campaign tersebut }\end{array}$ \\
\hline & & & $\begin{array}{c}\text { Peningkatan Alat Medis dan } \\
\text { Tenaga Medis }\end{array}$ & $\begin{array}{c}\text { Sediang } \\
\text { Dilaksanakan }\end{array}$ & Baik & $\begin{array}{l}\text { Tetap harus dilaksanaksan selvalipun } \\
\text { masih dalam fase normal spread }\end{array}$ \\
\hline
\end{tabular}




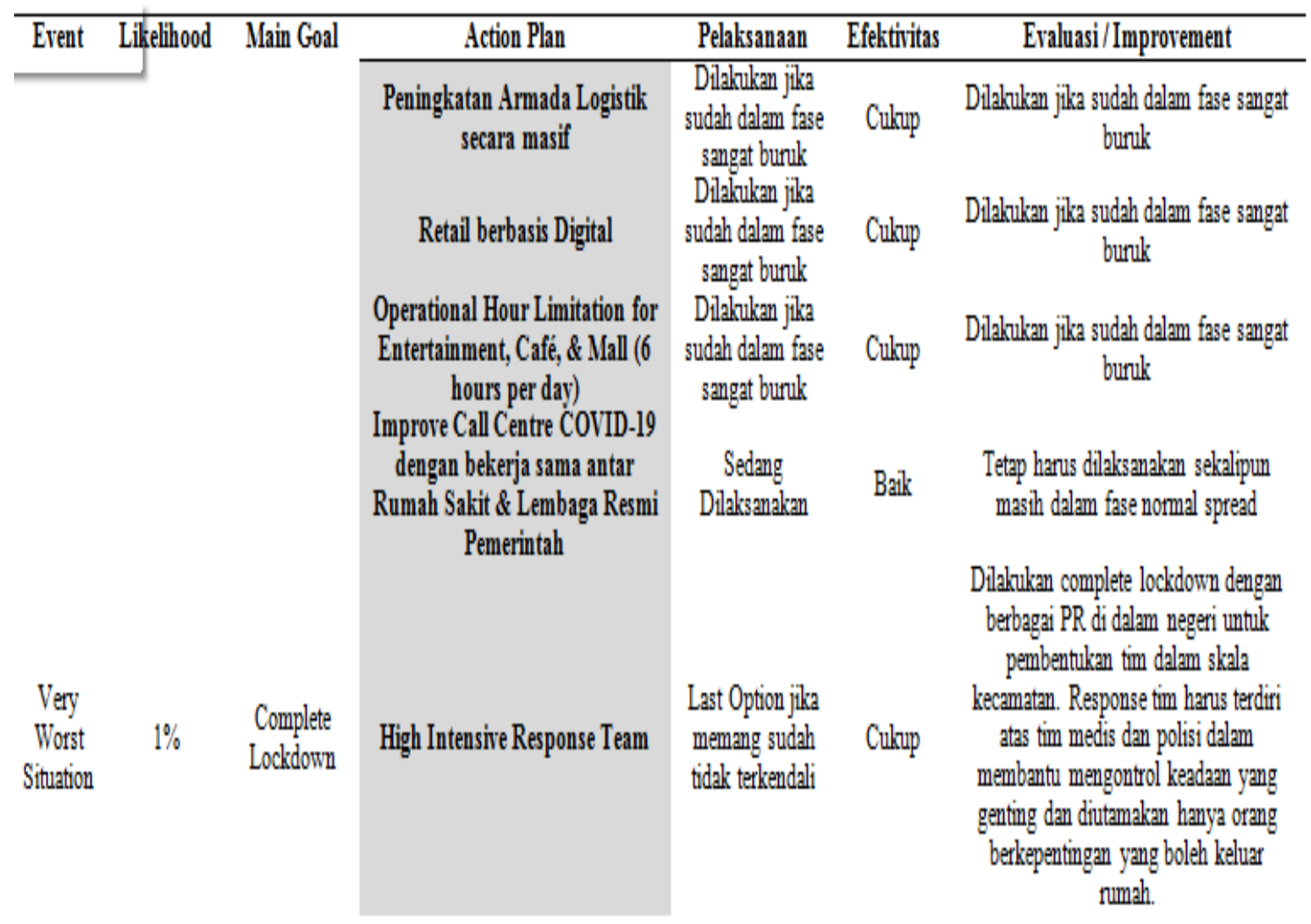

Pada akhirnya, jika memang terpaksa, maka opsi complete lockdown bisa diambil jika memang sudah sangat tidak bisa dikendalikan. Sejauh ini pemerintah sudah berusaha yang terbaik untuk pengendalian COVID-19 sekalipun terkesan lambat, akan tetapi dalam penanggulangan krisis tersebut memang dibutuhkan koordinasi dan kerja sama lintas instansi. Selama semua pihak yang berkepentingan dan masyarakat sadar betapa "gentingnya" situasi ini, maka peluang skenario $1 \%$, sebenarnya bisa dihindari. Mungkin memang tantangan terbesarnya adalah bagaimana memulihkan pasar modal yang telah hilang hampir 50\% nilainya, akan tetapi tentunya jika memang Indonesia berhasil mengatasi pandemic ini maka pasar modal tentunya bisa kembali ke titik semula. 


\section{KESIMPULAN}

Berikut ini adalah beberapa kesimpulan yang bisa diringkas dari hasil penelitian ini:

1. Kejadian turunnya IHSG pada Maret 2020 di Indonesia, menurut penulis belum bisa dikatakan black swan. Sejauh ini jika melihat pada pergerakan IHSG dari Desember 2019 hingga Februari 2020, maka terlihat indikasi bahwa pasar memang akan bergerak ke arah downtrend. Posisi pasar lebih tepatnya menunggu "berita" dari pemerintah mengenai apakah pandemik tersebut sudah tiba di Indonesia atau belum.

2. Pernyataan pada poin 1 memang harus diakui masih kurang dari sisi penjelasan ilmiah dan pendekatan statistik dengan model-model yang sophisticated untuk mengkonfirmasi bahwa IHSG sendiri akan terjun di bulan Maret 2020. Akan tetapi fokus penelitian ini ada pada bagaimana pembahasan sebuah unusual event dan contingency plan terhadap risiko itu. Untuk pembentukan model matematika yang rumit, penelitian ini mempercayakannya pada pengembangan penelitian selanjutnya

3. Event study dan juga Wilcoxon Signed Test mengkonfirmasi bulan Maret terdapat pergerakan yang tidak biasa dari IHSG. Korelasi antara IHSG, Nilai Tukar dan juga jumlah pasien COVID-19 juga sangat erat. Akan tetapi yang paling penting adalah bukan pada ditemukannya nilai korelasi yang kuat, melainkan pada action plan yang bisa diambil untuk meredam situasi tersebut.

4. Dalam penanganan risiko, digagas sebuah contingency plan sebagai "alat" bantu untuk mengantisipasi dan mendaftar tindakan-tindakan apa yang bisa diambil jika situasi $\mathrm{x}$ terjadi. Alat ini akan sangat membantu bagi pembuat kebijakan besar untuk negara ini, dan tentunya penulis percaya pemerintah juga sudah memiliki hal tersebut. Penelitian ini hanya memberikan sedikit gambaran dan ide bagaimana aplikasi contingency plan dapat diterapkan di saat krisis bagi pembaca artikel. 
5. Akhir kata, persatuan dan satu visi adalah kunci utama untuk keberhasilan penanggulangan COVID-19. Tanpa itu semua, jika masih ada beberapa pihak yang mengambil kesempatan

\section{DAFTAR PUSTAKA}

Aven, T. (2015). Implications of Black Swans to the Foundations and Practice of Risk Assessment and Management. Reliability Engineering and System Safety, 134, 83-91.

Aven, T. (2013). On the Meaning of a Black Swan in a Risk Context. Safety Science , 57, 44-51.

Ariely, D. (2010). Predictably Irrational. New York: Harper Perennial.

Graham, B., \& Zweig, J. (2006). The Intelligent Investor: The Definitive Book on Value Investing. A Book of Practical Counsel (Revised Edition). New York: Collins Business.

Kahneman, D. (2013). Think Fast and Slow. New York: Farrar, Straus and Giroux.

Krupa, J., \& Jones, C. (2013). Black Swan Theory: Applications to Energy Market Histories and Technologies. Energy Strategy Reviews , 1, 286-290.

Lin, W.-Y., \& Tsai, I.-C. (2019). Black Swan Events in China's Stock Markets: Intraday Price Behaviors on Days of Volatility. dan keuntungan dari situasi ini (terlihat dari penjual masker yang ingin cepat kaya di market place) maka kecepatan penanggulangan juga akan berjalan lambat.

International Review of Economics and Finance, 59, 395-411.

Ross, S. A., Westerfield, R. W., Jordan, B. D., Lim, J., \& Tan, R. (2014). Fundamental of Corporate Finance Asia Global Edition. McGraw Hill.

Taylor, J. B., \& Williams, J. C. (2008). A Black Swan in the Money Market. Federal Reserve Bank of San Fransisco.

Taleb, N. N. (2009). A Black Swan; Rahasia Terjadinya PeristiwaPeristiwa Langka yang Tak Terduga. Jakarta: Gramedia Pustaka Utama.

Thaler, R. (2009). Nudge: Improving Decisions About Health, Wealth, and Happiness. New York: Penguin.

Thaler, R. (2016). Misbehaving: The Making of Behavioral Economics. New York: W. W. Norton \& Company. 